\title{
Variability in Seed Parameters and Germination Allied Enzymes of Lentil Genotypes
}

\author{
Mampi Debbarma and Prabir Chakraborti* \\ Department of Seed Science and Technology, Bidhan Chandra Krishi Vishwavidhalaya, \\ Mohanpur-741252, West Bengal, India \\ *Corresponding author
}

\begin{tabular}{|l|}
\hline \multicolumn{1}{|l}{} \\
\hline Key w o r d s \\
Seed, Genetic \\
variability, Lentil, \\
Seed traits, \\
Enzymes \\
\hline Article Info \\
\hline $\begin{array}{l}\text { Accepted: } \\
10 \text { April } 2020 \\
\text { Available Online: } \\
10 \text { May } 2020\end{array}$ \\
\hline
\end{tabular}

\section{A B S T R A C T}

The observations were connected to assess the heritability of some seed traits and germination linked enzymes considering 10 Lentil genotypes. The 2(two) successive years showed significant hierarchy in $1^{\text {st }}$ year for seed traits though second year was best only in peroxidase activity. The maximum value was observed in PRE-COZ among genotypes for seed traits with enzyme activity. All genotypes showed high significant variations for the characters but, the interacted values of genotypes $\mathrm{x}$ year showed significant variation in seed length, pod wall dry weight, and enzymes activity though non-significant demarcation was followed for other traits of pod and seed. Results indicated the minimum deviation in genotypic coefficient of variation (GCV) and phenotypic coefficient of variation $(\mathrm{PCV})$ that recognized the genetic influence of considerable seed traits. High heritability $\left(\mathrm{H}^{2} \%\right)$ along with genetic advance indicated the influence of additive gene for all characters except seed breadth. In correlation matrix, the nonsignificant relationship was strictly followed in $\alpha$-amylase activity though it was highly correlated with peroxidase action. Strong positive correlation was followed within diverse seed traits and peroxidase activity. Therefore, the considerable parameters may be utilized in breeding schedule for quality seed production of Lentil.

\section{Introduction}

Lentil (Lens culinaris Medikus) cultivation is most wide spread in the world as cool-season grain legume crop after chickpea (Cicer arietinum L.) and pea (Pisum sativum L.) (FAO, 2015). In India, Lentil production is very much progressing among various countries in Asia due to its high acceptability in communities, simple cultivation methodology as well as unique nutritional status. Lentil seed usually contains $26 \%$ protein, best vegetable sources of iron and can be included in food regime of people 
exclusively that of low-earning stratum with balancing grains and useful for preventing nutrient deficiency especially for the poor. Legume crops are also significant components in farming systems, providing environmental and ecological benefits through crop rotation, specifically by supporting to soil fertility and rhizosphere diversity through biological $\mathrm{N}_{2}$ fixation.

Genetic variability is the pre-requisite for only plant breeding program where we can develop superior potentiality in qualitative and quantitative manner. Characterization consists of highly heritable characters can be valuable to establish better plant in addition to adaptation of wide environments. The experiment is undertaken to study the magnitude of genetic variability for creating the better scope in selection under crop improvement programme. Genetic parameters such as genotypic coefficient of variation (GCV) and phenotypic coefficient of variation (PCV) are useful in detecting the amount of variability present in the germplasm (Idris et al., 2012). Heritability and genetic advance are significant selection parameters in estimating the resultant effect in choice of best genotypes for yield and its attributing traits. Research efforts are going on to enhance the qualitative parameters of seed and pod through a few key markers on seed that was very meagre till date. Study on potentiality of seed through analysis of genetic variability considering different genotypes of Lentil, the morphological seed traits and two germination linked enzymes may be considered as assortment criteria to develop a good strain.

\section{Materials and Methods}

Ten (10) Lentil genotypes were sown in two successive years November, 2016 and 2017 under AB-Block Seed Farm, Bidhan Chandra Krishi Viswavidyalaya (BCKV), Nadia, and
West Bengal. In experiment, the considerable genotypes were WBL-81, DPL-62, SUBRATA, PL-639, WBL-77, PL-406, ASHA, KLS-218, K-75, and PRE-COZ which were laid out in Randomise block design (RBD) with three replications allowing for a specific plot size $2 \mathrm{~m} \times 3 \mathrm{~m}$ with $25 \mathrm{~cm}$ plant spacing. Suggested intercultural practices were done as and when required for accurate growth and development of the plants. After harvesting of the produce as seed material, the eight important seed traits were projected viz., pod length, pod breadth, seed length, seed breadth, pod wall dry weight, seed dry weight in addition to the activity of two germination allied enzymes $\alpha$-amylase (colorimetric method with DNS reagent) and Peroxidase (Kar and Mishra, 1976) at 24 hours stage of imbibition. The evaluation was done through statistical calculation of factorial design (2 factors) in CRD fashion considering OP Stat software. The genotypic and phenotypic coefficient of variation was assessed through the methods of Burton (1953). The other genetic parameters like broad sense heritability $\left(\mathrm{H}^{2} \%\right)$, genetic advance as percent mean (>20\%) were calculated through MS Excel (Johanson et al., 1955). Each character was recorded from fresh harvested seed of ten competitive plants in each plot as random basis.

\section{Results and Discussion}

The strategic approach on diverse research especially in breeding programme was very much dependent on plant specification, where varying configuration of seed in different genotypes should be explanatory (Biswas and Chakraborti, 2018). The study on different morphological parameters of pod and seed were obtained considering 10(ten) genotypes of Lentil in 2(two) successive years. The observation on pod and seed morphological pattern and biochemical parameters will be helpful to correlate the seed vigour in 
qualitative manner that can emphasize the knowledge on quality seed production. In pod length, the genotype PRE-COZ indicated its extreme performance among the genotypes where lowest length was noted in KLS218. The pod breadth was also an important factor in respect to economic yield of the crop through progression in size. Different genotypes showed significant variable measure by maintaining the top most value in PRE-COZ among all genotypes. The seed length was another crucial parameter for qualitative and quantitative up-gradation of the seed in addition to maintaining the genuineness of the particular genotype. In observation, the genotype PRE-COZ indicated the topmost value among the considerable genotypes and genotype PL-406 was the lowest. An additional parameter for maintaining the specificity of a genotype was seed breadth. In observation on genotypes, the maximum value was detected in PRE-COZ followed by PL-639 with a significant demarcation within them as well as other considerable genotypes. The pod wall dry weight indicated actual dry matter assimilation in a pod at the time of distribution of photosynthates into sink where the genotype PRE-COZ specified its superiority considering all the values in progression of seed under a significant demarcation. Significant variability was also prominent in seed dry weight where dry matter accumulation will be helpful in displaying of seed vigour. Maximum value of PRE-COZ genotype maintained distinct demarcation with all however, a few of them displayed non-significant relationship.

The activity of enzyme $\alpha$-amylase and peroxidase was very much interrelated to seed activity particularly in advancement of germination initiation (Ahsan et al., 2007). In genotypes, the mean value for $\alpha$-amylase activity displayed significant variation where maximum value was observed in PRE-COZ followed by ASHA and KLS-218.The isozyme peroxidase activity was valuable for creating defence mechanism of a plant or seed predominantly in seed germination due to its attuned activity in protection of seed (Singh $e t$ al., 2015). The significant variability was observed among different genotypes where maximum value was detected in PRE-COZ followed by K-75.

In observation of 2 (two) successive years comprising the mean value of varieties, a significant demarcation was exhibited in both years for all the characters except in seed breadth $(\mathrm{mm})$ and $\alpha$-amylase activity. The interaction of two factors i.e. genotype $x$ year (Y) showed a significant variation in seed length, pod wall dry weight, activity of $\alpha$ amylase and peroxidase activity may be due to environmental in stability. The significant variation among different genotypes considering selected traits was effective for plant breeders and it was highly active in extreme degree of variation (Dhanwani et al., 2013; Debbarma et al., 2018).

The value of genotypic co-efficient of variation $(\mathrm{GCV})$ and phenotypic co-efficient of variation (PCV) showed the genetic pressure of these seed traits demonstrating prominent genetic influence for all traits which may be supportive in selection of good strain (Seyoum et al., 2012). The degree of variances between phenotypic coefficient of variability and genotypic coefficient of variability was detected to be somewhat low for all the traits matching to the observation of Parvathi et al., (2011). High heritability $\left(\mathrm{H}^{2} \%\right)$ in addition to high genetic advance (GA \%) as per cent mean (>20\%) highlighted the action of additive gene for these characters. High heritability $\left(\mathrm{H}^{2} \%\right)$ with high genetic advance was observed for most of the characters viz., pod length, pod breadth, seed length, pod wall dry weight and seed dry weight, though a few exceptions was 
observed in seed breadth as well as the activity of $\alpha$-amylase and peroxidase only for $2^{\text {nd }}$ year. So, the designated seed traits may be careful for selection criteria in up-gradation of lentil seed production identical to the remark of Abebe et al., (2017) and Mandal et al., (2019). In seed morphology, the different characters showed high heritability $\left(\mathrm{H}^{2} \%\right)$ and genetic advance (GA \%) that can be suitable as selection parameters for advancement of good strain similar to the study of Biswas and
Chakraborti (2019). The correlation matrix of the different seed traits represented (table 3) the value, 0.3819 for $\mathrm{R}^{2}$ which indicated the significant positive relationship was prevailing for the considerable characters similar to the observation on Rice (Biswas and Chakraborti, 2019). The positive significant mode was observed for most of the characters though an exception was revealed in $\alpha$-amylase under non-significant mode.

Table.1 Variability in seed traits considering diverse genotypes of Lentil

\begin{tabular}{|c|c|c|c|c|c|c|c|c|}
\hline Genotypes & $\begin{array}{c}\text { Pod } \\
\text { length } \\
\text { (cm) }\end{array}$ & $\begin{array}{c}\text { Pod } \\
\text { breadth } \\
(\mathbf{c m})\end{array}$ & $\begin{array}{c}\text { Seed } \\
\text { length } \\
(\mathbf{m m})\end{array}$ & $\begin{array}{c}\text { Seed } \\
\text { breadth } \\
(\mathbf{m m})\end{array}$ & $\begin{array}{l}\text { Pod walldry } \\
\text { weight (mg) }\end{array}$ & $\begin{array}{l}\text { Seed dry } \\
\text { weight } \\
\text { (mg) }\end{array}$ & $\begin{array}{c}\alpha \text {-Amylase } \\
\text { activity } \\
\left(\mu \mathrm{g} \mathrm{\text {min } ^ { - 1 }} \mathrm{g}^{-1}\right)\end{array}$ & $\begin{array}{c}\text { Peroxidase } \\
\text { activity } \\
\left(\Delta \mathrm{Amin}^{-1} \mathrm{~g}^{-1}\right)\end{array}$ \\
\hline WBL-81 & 1.10 & 0.68 & 3.74 & 2.66 & 94.98 & 215.67 & 55.54 & 1.14 \\
\hline DPL-62 & 1.09 & 0.70 & 3.72 & 2.60 & 95.45 & 214.50 & 57.99 & 1.23 \\
\hline SUBRATA & 1.12 & 0.70 & 3.53 & 2.57 & 120.85 & 222.00 & 60.87 & 1.28 \\
\hline PL-639 & 1.12 & 0.68 & 3.59 & 2.87 & 98.25 & 210.83 & 65.83 & 1.29 \\
\hline WBL-77 & 1.12 & 0.69 & 3.58 & 2.64 & 101.60 & 204.50 & 66.83 & 1.30 \\
\hline PL-406 & 1.12 & 0.67 & 3.33 & 2.44 & 100.93 & 201.33 & 67.29 & 1.21 \\
\hline ASHA & 1.13 & 0.68 & 3.41 & 2.70 & 101.60 & 221.17 & 67.93 & 1.25 \\
\hline KLS-218 & 1.04 & 0.65 & 3.40 & 2.52 & 94.55 & 215.17 & 67.89 & 1.26 \\
\hline K-75 & 1.16 & 0.70 & 3.65 & 2.57 & 100.60 & 216.00 & 65.91 & 1.42 \\
\hline PRE-COZ & 1.59 & 0.91 & 5.80 & 3.02 & 139.82 & 408.00 & 74.72 & 1.48 \\
\hline SEm ( $( \pm)$ & 0.009 & 0.005 & 0.026 & 0.037 & 1.321 & 2.662 & 0.476 & 0.008 \\
\hline LSD 0.05 & 0.025 & 0.014 & 0.076 & 0.107 & 3.791 & 7.637 & 1.366 & 0.022 \\
\hline
\end{tabular}

Table.2 Variability in years considering seed traits and the effect of interaction

\begin{tabular}{|c|c|c|c|c|c|c|c|c|}
\hline & $\begin{array}{l}\text { Pod } \\
\text { length } \\
(\mathrm{cm})\end{array}$ & $\begin{array}{c}\text { Pod } \\
\text { breadth } \\
(\mathrm{cm})\end{array}$ & $\begin{array}{c}\text { Seed } \\
\text { length } \\
(\mathbf{m m})\end{array}$ & $\begin{array}{c}\text { Seed } \\
\text { breadth } \\
(\mathbf{m m})\end{array}$ & $\begin{array}{l}\text { Pod wall } \\
\text { dry weight } \\
\text { (mg) }\end{array}$ & $\begin{array}{c}\text { Seed dry } \\
\text { weight } \\
\text { (mg) }\end{array}$ & $\begin{array}{c}\alpha \text {-Amylase } \\
\text { activity } \\
\left(\mu \mathrm{g} \mathrm{min}^{-1} \mathrm{~g}^{-1}\right)\end{array}$ & $\begin{array}{c}\text { Peroxidase } \\
\text { activity } \\
\left(\Delta \mathrm{Amin}^{-1} \mathbf{g}^{-1}\right)\end{array}$ \\
\hline Y1 & 1.17 & 0.71 & 3.80 & 2.67 & 106.89 & 240.37 & 65.29 & 1.24 \\
\hline Y2 & 1.15 & 0.70 & 3.75 & 2.65 & 102.83 & 225.47 & 64.87 & 1.33 \\
\hline $\operatorname{SEm}( \pm)$ & 0.004 & 0.002 & 0.012 & 0.017 & 0.591 & 1.19 & 0.213 & 0.004 \\
\hline LSD 0.05 & 0.011 & 0.006 & 0.034 & NS & 1.695 & 3.415 & NS & 0.01 \\
\hline \multicolumn{9}{|c|}{ Interaction of genotypes and years $(\mathrm{V} \times \mathrm{Y})$} \\
\hline $\operatorname{SEm}( \pm)$ & 0.012 & 0.007 & $\mathbf{0 . 0 3 7}$ & 0.053 & 1.869 & 3.765 & 0.673 & 0.011 \\
\hline LSD 0.05 & NS & NS & 0.107 & NS & 5.361 & NS & 1.932 & 0.032 \\
\hline
\end{tabular}

NS- Non-Significant, Y1- $1^{\text {st }}$ year, Y2-2 ${ }^{\text {nd }}$ year 
Table.3 Genetic variability in different seed traits considering two years observations

\begin{tabular}{|l|c|c|c|c|c|c|c|c|}
\hline PARAMETERS & \multicolumn{2}{|c|}{ GCV } & \multicolumn{2}{c|}{ PCV } & \multicolumn{2}{c|}{$\mathbf{H}^{\mathbf{2} \%}$} & \multicolumn{2}{c|}{ GA\% } \\
\hline Pod length & Y1 & Y2 & Y1 & Y2 & Y1 & Y2 & Y1 & Y2 \\
\hline Pod breadth & 2.52 & 2.42 & 2.53 & 2.42 & 99.45 & 99.44 & 32.59 & 31.45 \\
\hline Seed length & 1.47 & 1.52 & 1.48 & 1.52 & 99.15 & 99.56 & 24.36 & 25.38 \\
\hline Seed breadth & 6.46 & 6.48 & 6.47 & 6.48 & 99.54 & 99.91 & 46.27 & 46.81 \\
\hline Pod wall dry weight & 1.85 & 1.90 & 1.98 & 1.93 & 87.44 & 97.21 & 14.83 & 16.11 \\
\hline Seed dry weight & 27.06 & 22.32 & 27.39 & 22.39 & 97.61 & 99.41 & 36.21 & 30.73 \\
\hline a-Amylase activity & 71.16 & 69.19 & 71.36 & 69.22 & 99.42 & 99.90 & 64.07 & 64.48 \\
\hline Peroxidase activity & 16.11 & 9.48 & 16.21 & 9.53 & 98.78 & 98.83 & 27.74 & 16.38 \\
\hline
\end{tabular}

GCV-Genotypic coefficient of variation; PCV-Phenotypic coefficient of variation;

$\mathbf{H}^{2}$-Heritability; GA-Genetic advance; Y1- $1^{\text {st }}$ year, Y2-2 $2^{\text {nd }}$ year

Table.4 Correlation Matrix of different seed traits

\begin{tabular}{|c|c|c|c|c|c|c|c|}
\hline & $\begin{array}{c}\text { Pod } \\
\text { length }\end{array}$ & $\begin{array}{c}\text { Pod } \\
\text { breadth }\end{array}$ & $\begin{array}{c}\text { Seed } \\
\text { length }\end{array}$ & $\begin{array}{c}\text { Seed } \\
\text { breadth }\end{array}$ & $\begin{array}{c}\text { Pod wall } \\
\text { dry } \\
\text { weight }\end{array}$ & $\begin{array}{c}\text { Seed dry } \\
\text { weight }\end{array}$ & $\begin{array}{c}\alpha \text {-amylase } \\
\text { activity }\end{array}$ \\
\hline Pod breadth & $0.985^{* *}$ & & & & & & \\
\hline Seed length & $0.968^{* *}$ & $0.985^{* *}$ & & & & & \\
\hline Seed breadth & $0.754^{*}$ & $0.748^{*}$ & $0.777^{* *}$ & & & & \\
\hline $\begin{array}{c}\text { Pod wall } \\
\text { dryweight }\end{array}$ & $0.874^{* *}$ & $0.883^{* *}$ & $0.819^{* *}$ & $0.584^{\mathrm{NS}}$ & & & \\
\hline $\begin{array}{c}\text { Seed dry } \\
\text { weight }\end{array}$ & $0.974^{* *}$ & $0.977^{* *}$ & $0.981^{* *}$ & $0.751^{*}$ & $0.866^{* *}$ & & \\
\hline $\begin{array}{c}\alpha \text { - amylase } \\
\text { activity }\end{array}$ & $0.618^{\mathrm{NS}}$ & $0.524^{\mathrm{NS}}$ & $0.487^{\mathrm{NS}}$ & $0.416^{\mathrm{NS}}$ & $0.513^{\mathrm{NS}}$ & $0.581^{\mathrm{NS}}$ & \\
\hline $\begin{array}{l}\text { Peroxidase } \\
\text { activity }\end{array}$ & $0.747^{*}$ & $0.731^{*}$ & $0.681^{*}$ & $0.533^{\mathrm{NS}}$ & $0.678^{*}$ & $0.692^{*}$ & $0.705^{*}$ \\
\hline
\end{tabular}

NS- Non-Significant;* Significant; **Highly significant

The non-significant relationship was also followed in between pod wall dry weight and seed breadth though some other attributes were also positively significant with these two characters. The non-significant relationship of $\alpha$-amylase indicated its independent relationship with seed morphology but its activity was closely related to peroxidase activity predominantly on the basis of genotypic nature.

The specific knowledge on ecological pressure such as temperature, water availability and solar effect etc. was not ample in respect to the crop, Lentil. Wang and Daun (2004) established the association of compositional factors with environmental conditions in variable seed traits specifically on bio-molecular components. Al-Karaki and Ereifej (1999) studied the effect of cultivars, field pea on rainfall and temperature where modification was assorted with exterior and interior level of seed development. Therefore, the present study considering various seed related parameters in different years was pertinent and the scope of enhancement of 
lentil genotypes utilizing these seed traits may be considerable in selection procedure.

In conclusion, the overall result specified a core set of germplasm with high genetic variability where PRE-COZ followed by K-75 in addition to WBL-81 may be suitable for quality seed production. The broad sense heritability and genetic advance as percentage of mean indicated that all parameters except seed breadth showed significant characteristic on seed and selection based on these traits would be very real for Lentil genotypes predominantly in upgradation of seed production.

\section{References}

Abebe, T., Alamerew, S. and Tulu, L. 2017. Genetic Variability, Heritability and Genetic Advance for Yield and its Related Traits in Rainfed Lowland Rice (Oryza sativa L.) Genotypes at Fogera and Pawe, Ethiopia. Advances in Crop Science and Technology. 5(2): 272.

Ahsan, N., Lee, D.-G., Lee, S.-H., Kang, K.Y., Lee, J.J., Kim, P.J., Yoon, H.-S., Kim, J.-S., Lee, B.-H.2007. Excess copper induced physiological and proteomic changes in germinating rice seeds. Chemosphere.67: 1182-1193.

Al-Karaki, G.N. and Ereifej, K.I. 1999. Relationships between seed yield and chemical composition of field peas grown under semi-arid Mediterranean conditions. Journal of Agronomy and Crop Science. 182: 279-284.

Biswas, U. and Chakraborti, P. 2018. Genetic variability in seedling pattern of rice genotypes under water stress and normal condition. Journal of Pharmacognosy and Phytochemistry. 7(4): 3177-3179.

Biswas, U. and Chakraborti, P. 2019. Variability in aromatic and nonaromatic rice genotypes considering seed morphology with some biomolecules. International Journal of Chemical Studies. 7(3): 3648-3651.

Burton, G.W. and De, V.E.H. 1953. Estimating heritability in tall fescue (Festuca arundinacea) from replicated clonal material. Agronomy Journal.45: 478-481.

Debbarma, M., Laloo, B., Mandal, J., Chakraborti, P. 2018. Genetic variability in yield attributes of Lentil genotypes under new alluvial zone. Current Journal of Applied Science and Technology. 30(5):1-6.

Dhanwani, R.K., Sarwgi, A.K., Solanki, A., Tiwari J. K. 2013. Genetic variability analysis for various yield attributing and quality traits in rice (Oryza sativa L.). The Bioscan. 8(4):1403-1407.

FAO (2015). FAO STAT. Food and Agriculture Organization of the United Nations, Rome: Available online at: http://faostat.fao.org

Idris, A.E., Justin, F.J., Dagash, Y.M.I. and Abuali, A.I. 2012. Genetic Variability and Inter Relationship between Yield and Yield Components in Some Rice Genotypes. American Journal of Experimental Agriculture. 2(2): 233239.

Johnson, W.W., Robinson, H.F., Comstock, R.E. 1955. Genotypic and phenotypic correlation in soybeans and their implications in selection. Agron. J. 47:477-482.

Kar, M., Mishra, D.1976. Catalase, peroxidise and polyphenoloxidase activities during rice leaf senescence. Plant Physiology. 57:315-319.

Mandal, S., Biswas, U. and Chakraborti, P. 2019. Genetic Variability in Seed Traits Considering Some Genotypes of Wheat. Current Journal of Applied Science and Technology.38(6): 1-8.

Parvathi, P.S., Rao, V. S., Ahmed, M. L., Anilkumar, P. 2011. Correlation and 
path analysis of yield and quality attributes in rice. The Andhra Agriculture Journal. 58(3): 310-314.

Seyoum, M., Alamesew, S., Bantte, K.2012. Genetic variability, heritability correlation coefficient and path analysis for yield and yield related traits in upland rice (Oryza sativa L.). Journal Plant Science.7 (1):13-22.
2015. Role of peroxidase activity and $\mathrm{Ca}^{2+}$ in axis growth during seed germination; Planta. 242: 997-1007.

Wang, N. and Daun, J.K. 2006. Effect of variety and crude protein content on nutrients and anti-nutrients in lentils (Lens culinaris). Food Chemistry.95:493-502.

Singh, K.L., Chaudhuri, A. and Kar, R.K.

\section{How to cite this article:}

Mampi Debbarma and Prabir Chakraborti. 2020. Variability in Seed Parameters and Germination Allied Enzymes of Lentil Genotypes. Int.J.Curr.Microbiol.App.Sci. 9(05): 11851191. doi: https://doi.org/10.20546/ijcmas.2020.905.131 